\title{
Zrobotyzowane spawanie Laser SEAM Stepper stali wysokowytrzymałej DOCOL 1200M
}

\author{
Robotic welding of high-strength DOCOL 1200M steel \\ with Laser SEAM Stepper system
}

\begin{abstract}
Streszczenie
W pracy zostanie przedstawiony wpływ parametrów procesu łączenia na strukturę i własności połączeń spawanych na zakładkę stali DOCOL 1200M o grubości 1,8 mm techniką Laser SEAM Stepper. Stal DOCOL 1200M o strukturze martenzytycznej, przeznaczona jest głównie na wytwarzanie zderzaków samochodowych, belek bocznych oraz innych elementów zapewniających bezpieczeństwo użytkownika pojazdów mechanicznych. Uzyskane złącza spawane zostały poddane badaniom metalograficznym mikro- i makroskopowym oraz pomiarowi twardości. Przeprowadzone badania wizualne oraz badania nieniszczące pozwoliły na opracowanie pola parametrów spawania pozwalające uzyskać połączenia z pełnym przetopem (w zależności od wymagań) lub połączenia bez pełnego przetopienia. Dla zadanych parametrów spawania, tj. prędkości posuwu oraz długości spoiny, które są stałe, rzeczywista długość spoiny jest uwarunkowana częstotliwością przesuwu wiązki laserowej. Wraz ze wzrostem mocy spawania zwiększa się głębokość przetopu. Badania mikroskopowe w obszarze spoiny ujawniły w każdym przypadku strukturę martenzytyczną, przy czym wraz ze wzrostem energii liniowej spawania wielkość igieł martenzytu rośnie, zwłaszcza w stosunku do materiału rodzimego. W SWC dochodzi do odpuszczenia struktury martenzytycznej. Wykazano, że dla odpowiednio dobranych parametrów metoda Laser SEAM Stepper nadaje się do zgrzewania stali DOCOL 1200M.
\end{abstract}

Słowa kluczowe: stal DOCOL 1200M; Laser SEAM Stepper; spawani laserowe; martenzyt

\begin{abstract}
This paper will present the influence of joining process parameters on the structure and properties of overlapped welded joints of $1.8 \mathrm{~mm}$ DOCOL $1200 \mathrm{M}$ steel using Laser SEAM Stepper method. The Laser SEAM Stepper (LSS) system by IPG Laser $\mathrm{GmbH}$ combines the advantages of laser-beam welding with the use of attached pressing unit. The DOCOL $1200 \mathrm{M}$ martensitic steel is mainly intended for manufacturing car bumpers, side bars and other user-safety elements of motor vehicles. The obtained welded joints were subjected to micro- and macroscopic metallographic examination and hardness measurement. The visual inspections and non-destructive testing made it possible to develop the field of welding parameters to allow obtaining full penetration joints (depending on requirements) or partial penetration joints. For present welding parameters, i.e. rate of feed and length of weld, which are constant, the actual length of weld is determined by welding frequency. With the increase in welding power, the penetration depth increases. In each case, the microscopic examinations revealed martensitic structure in the weld area, and with the increase in linear welding energy the size of martensite needles became larger, especially in relation to the native material. In HAZ, the martensitic structure is tempered. It has been shown that with appropriately selected parameters the Laser SEAM Stepper method is suitable for welding the DOCOL $1200 \mathrm{M}$ steel.
\end{abstract}

Keywords: DOCOL 1200M steel; Laser SEAM Stepper; welding; martensitic

\section{Wstęp}

Producenci stali wytwarzają coraz to nowsze materiały, o lepszych własnościach, które są odpowiedzią na zapotrzebowanie między innymi przemysłu motoryzacyjnego. Przyczyną tego są wysokie wymagania związane z bezpieczeństwem użytkowników oraz ciągły trend redukcji wagi wytwarzanych konstrukcji. Pozwala to na sporą redukcję masy pojazdów, zmniejszenie ich zapotrzebowania na paliwo oraz zmniejszenie emisji szkodliwych gazów do otoczenia. W celu zaspokojenia tego zapotrzebowania przemysłu motoryzacyjnego powstały stale o wysokiej wytrzymałości

Dr hab. inż. Jacek Górka, prof. Pol. Śl. - Politechnika Śląska, mgr inż. Andrzej Ozgowicz - Stryvo AS, Norway.

Autor korespondencyjny/Corresponding author: jacek.gorka@polsl.pl 
AHSS (ang. Advanced High-Strength Steel). Materiały te sprawdziły się świetnie w produkcji pojazdów za sprawą trzech bardzo istotnych cech: dużej wytrzymałości na rozciąganie, do $1700 \mathrm{MPa}$, dużej granicy plastyczności, do $1450 \mathrm{MPa}$ oraz dużego wydłużenia $A_{80}$, do $30 \%[1 \div 4]$. Istotnym jest również fakt, że stosunkowo łatwa jest obróbka plastyczna oraz obróbka skrawaniem tych stali. Stale wysokowytrzymałe AHSS chętnie wykorzystywane są w przemyśle motoryzacyjnym, ponieważ dają możliwość zmniejszenia grubości blach karoseryjnych oraz elementów nośnych karoserii przy jednoczesnym wzroście własności mechanicznych w zestawieniu ze stalami konwencjonalnymi. Dodatkowym atutem stali AHSS jest stosunkowo niska cena, za sprawą małej ilości dodatków stopowych w stali. Pomimo faktu, że stale projektowane były z myślą o łączeniu ich poprzez procesy spajania metodami spawalniczymi, niektóre z nich wciąż stanowią problem w opracowaniu metody i opty-

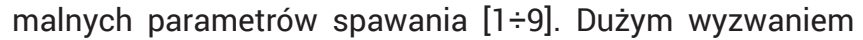
jest łączenie wysokowytrzymałej stali DOCOL 1200M o strukturze martenzytycznej, przeznaczonej głównie na wytwarzanie zderzaków samochodowych, belek bocznych oraz innych elementów zapewniających bezpieczeństwo użytkownika pojazdów mechanicznych. W tym zakresie ciągle duże znaczenie odgrywa proces zgrzewania punktowego. Technologia zgrzewania oporowego umożliwia łączenie elementów metalowych umiejscowionych pomiędzy elektrodami zgrzewarki. W czasie procesu zgrzewania punktowego zgrzeina może zostać wykonana w jednym lub kilku punktach jednocześnie. Ograniczona jest natomiast liczba elementów łączonych w jednym punkcie - maksymalnie można zgrzać trzy różne elementy [11]. Technologia zgrzewania oporowego punktowego jest procesem stosunkowo łatwym w automatyzacji i robotyzacji. Z racji tego, jest to metoda łączenia elementów metalowych wykorzystywana na szeroką skalę w przemyśle. Przedmioty najczęściej łączone w ten sposób to blachy ze stali niestopowych oraz stopowych w urządzeniach i sprzęcie gospodarstwa domowego, sprzęcie elektrycznym i elektronicznym, a także elementach maszyn [12]. Przemysł motoryzacyjny również opiera się na tej metodzie zgrzewania. Zgrzewane punktowo są elementy samochodów oraz innych pojazdów - zastosowanie przy produkcji karoserii samochodowych mają gniazda zrobotyzowanego zgrzewania oporowego punktowego [13]. Alternatywą dla tej metody może być proces System Laser SEAM Stepper (LSS) firmy IPG Laser GmBH [14]. System LSS umożliwia wykonywanie spoin o długości do $40 \mathrm{~mm}$, a dodatkowo przy odpowiedniej częstotliwości sinusoidalnej trajektorii przesuwu wiązki, która zawiera się w przedziale od 3 do $30 \mathrm{~Hz}$, ich szerokość może osiągać $2 \mathrm{~mm}$. Standardowa długość spoiny wynosi ok. $30 \mathrm{~mm}$ przy jednakowych odstępach między kolejnymi przejściami. Prędkość przejścia dla takiego procesu wynosi ok. $30 \mathrm{~mm} / \mathrm{s}$, rysunek 1 .

\section{Badania własne}

Celem badań było określenie struktury i własności złączy zakładkowych blach o grubości 1,8 mm ze stali niskostopowej wysokowytrzymałej DOCOL 1200M, o strukturze martenzytycznej łączonych techniką Laser SEAM Stepper (LSS) przy zastosowaniu zmiennych parametrów procesu: mocy wiązki laserowej, częstotliwości sinusoidalnej trajektorii przesuwu wiązki. Rzeczywisty skład chemiczny i własności stali DOCOL 1200M przedstawia tablica I, a strukturę rysunek 2.

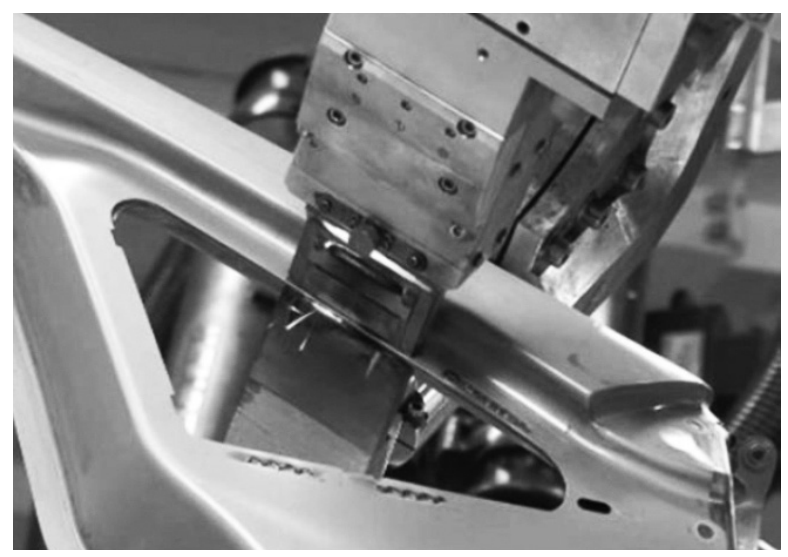

Rys. 1. Pracujący LSS przy trójkątnym oknie samochodowym Fig. 1. LSS working at a triangle car window

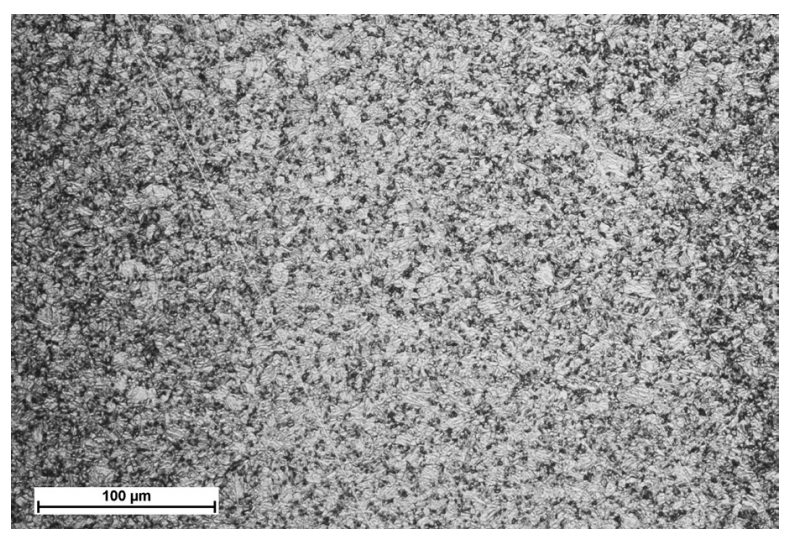

Rys. 2. Martenzytyczna struktura stali DOCOL $1200 \mathrm{M}$

Fig. 2. Martensitic microstructure of DOCOL $1200 \mathrm{M}$ steel

Tablica I. Skład chemiczny i własności mechaniczne stali martenzytycznej DOCOL 1200M

Table I. The chemical composition and mechanical properties of martensitic DOCOL 1200M steel

\begin{tabular}{|c|c|c|c|c|c|c|c|c|c|c|c|}
\hline \multicolumn{12}{|c|}{ Stężenie pierwiastków, \% } \\
\hline C & Si & $\mathrm{Mn}$ & $\mathbf{P}$ & S & Al & Nb & v & $\mathrm{Ni}$ & $\mathrm{Cr}$ & $\mathbf{N}$ & $\mathrm{Ce}^{\star}$ \\
\hline 0,113 & 0,22 & 1,58 & 0,01 & 0,002 & 0,035 & 0,016 & 0,01 & 0,04 & 0,04 & 0,006 & 0,39 \\
\hline \multicolumn{12}{|c|}{ Własności mechaniczne } \\
\hline \multicolumn{4}{|c|}{ Wytrzymałość na rozciąganie $R_{m}, M P a$} & \multicolumn{4}{|c|}{ Granica plastyczności $R_{e}, M P a$} & \multicolumn{4}{|c|}{ Wydłużenie $A_{80}, \%$} \\
\hline \multicolumn{4}{|c|}{1260} & \multicolumn{4}{|c|}{1060} & \multicolumn{4}{|c|}{5} \\
\hline \multicolumn{12}{|c|}{ * Ce - równoważnik węgla } \\
\hline
\end{tabular}




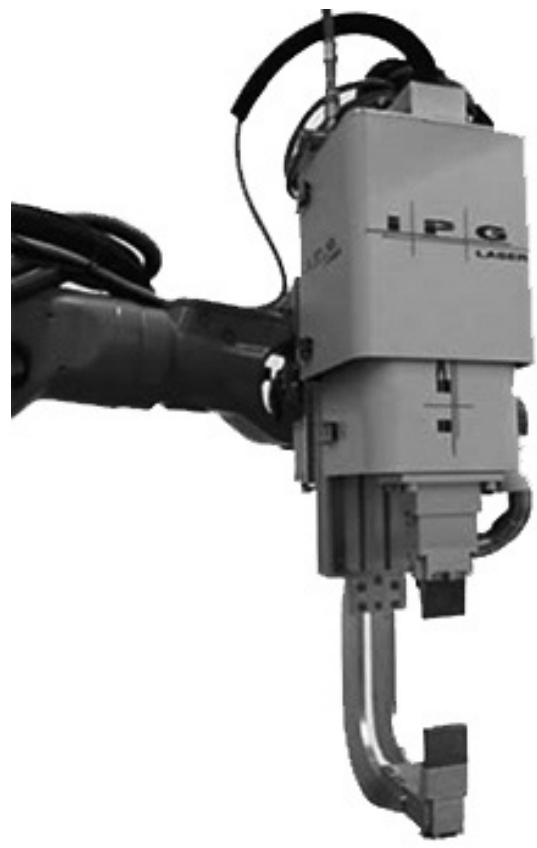

Rys. 3. Widok stanowiska do spawania Laser SEAM Stepper wykorzystana w badaniach

Fig. 3. The view of Laser SEAM Stepper welding station

\section{Proces łączenia}

Wykonano 8 złączy próbnych przy zmiennych parametrach procesu z wykorzystaniem laserowej głowicy roboczej firmy IPG umieszczonej na kiści robota przemysłowego (rys. 3). Parametry procesu łączenia przedstawia tablica II, a wygląd połączeń rysunek 4 .

\section{Badania uzyskanych połączeń}

Uzyskane złącza spawane po przeprowadzeniu badań wizualnych poddano badaniom niszczącym w takim zakresie jak:

- badania metalograficzne makroskopowe na mikroskopie świetlnym stereoskopowym Olympus SZX9; próbki do badań trawiono odczynnikiem Adlera;

- badania metalograficzne mikroskopowe na mikroskopie świetInym NIKON ECLIPSE MA100; próbki do badań trawiono w nitalu;

- pomiar twardości za pomocą urządzenia Vickers 401MVD firmy Wilson Wolpert, przy obciążeniu $1 \mathrm{~kg}$, wzdłuż jednej linii pomiarowej w obszarze przetopienia i SWC.
LICO
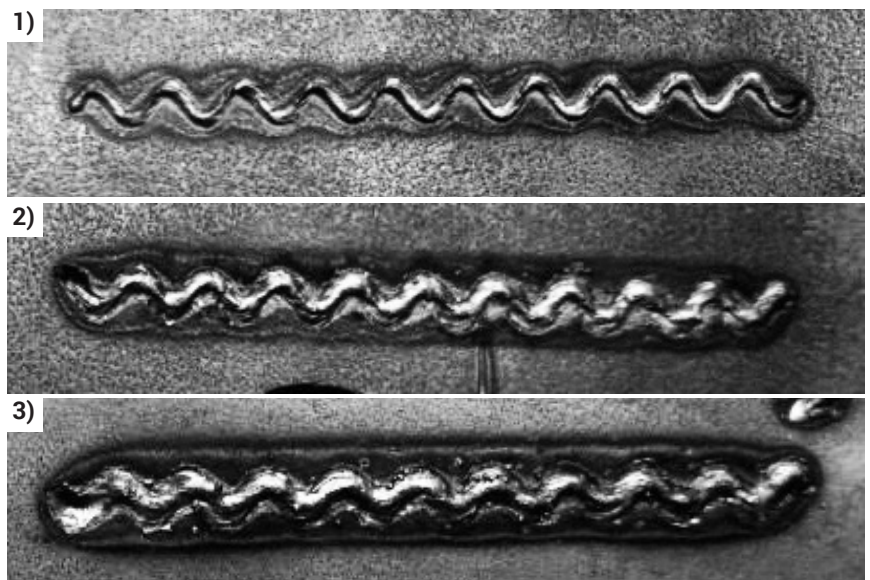

4)
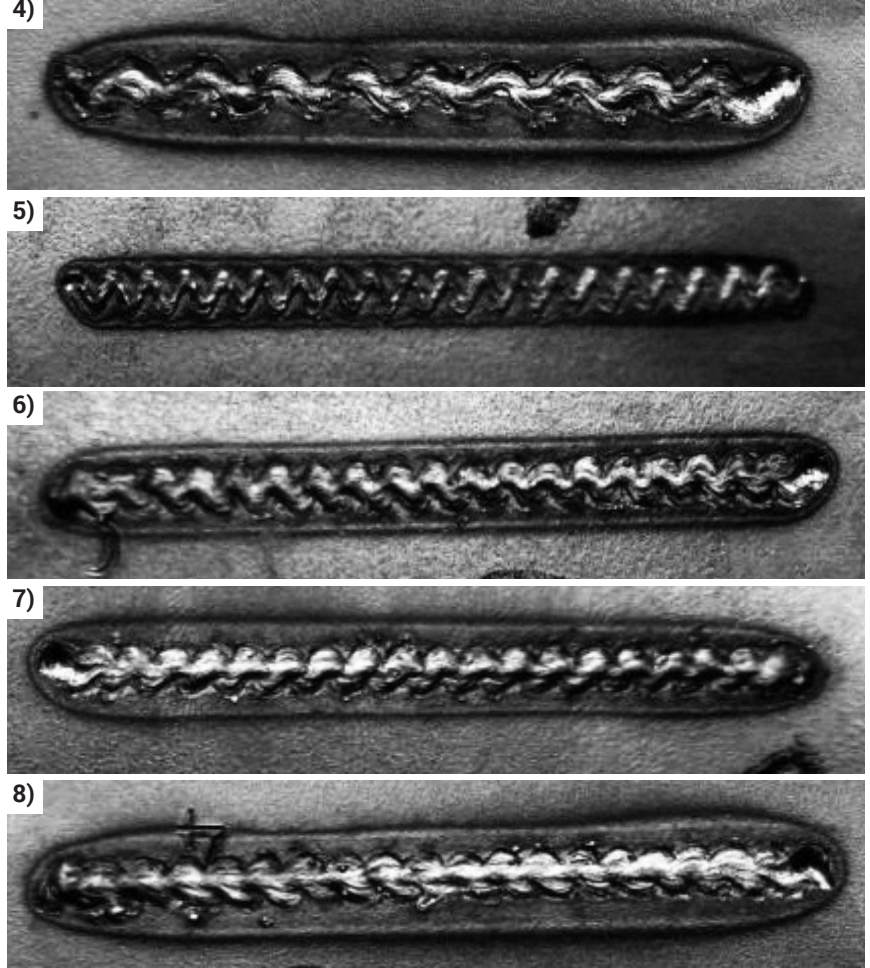

Rys. 4. Widok od strony lica i grani połączeń, wg kolejności - tablica II Fig. 4. The view from the weld face and root side, order as per Table II

\section{GRAŃ}
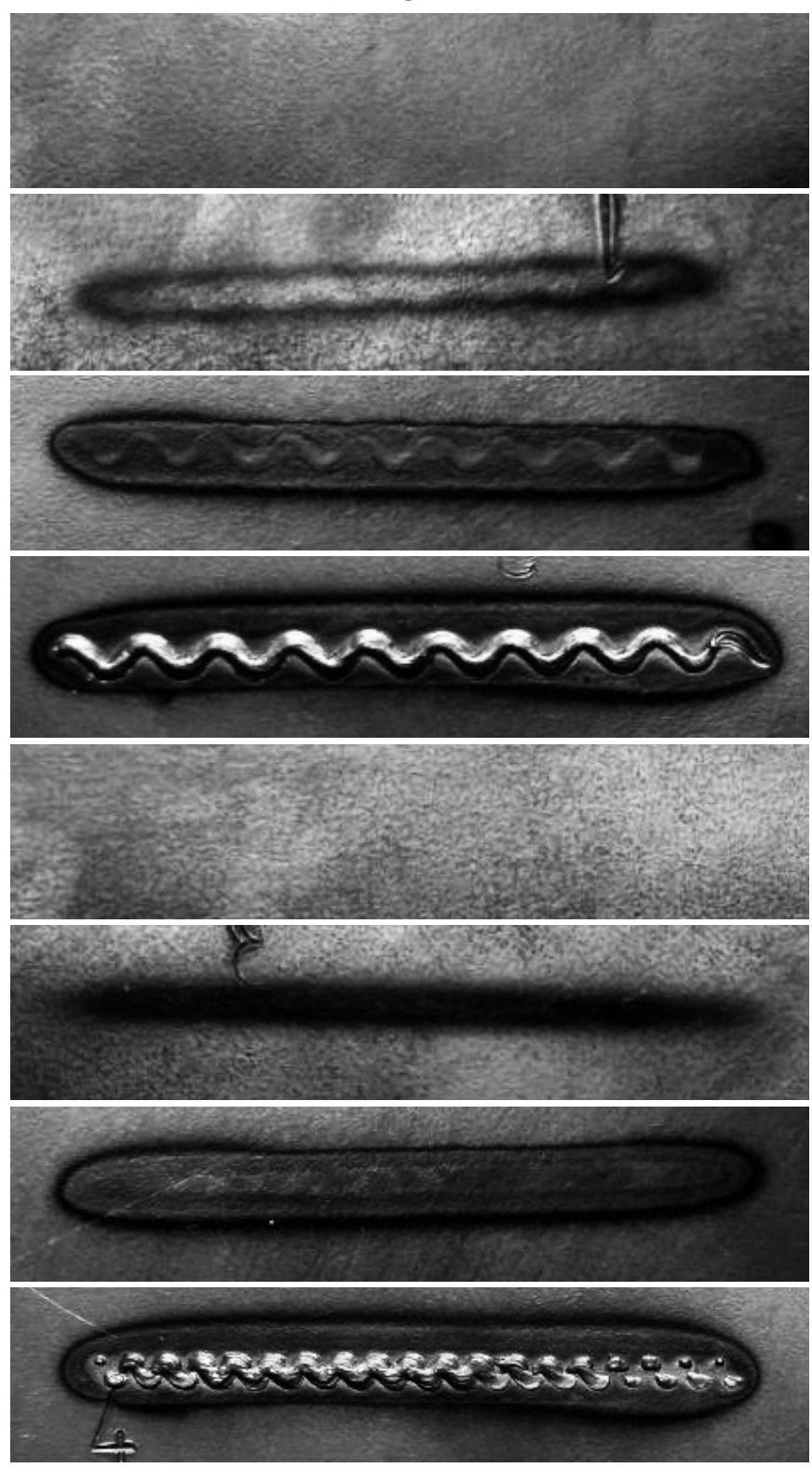
Tablica II. Parametry procesu łączenia

Table II. Joining process parameters

\begin{tabular}{|c|c|c|c|c|c|c|}
\hline $\begin{array}{l}\text { Oznaczenie } \\
\text { złącza }\end{array}$ & $\begin{array}{c}\text { Moc wiązki } \\
\text { laserowej, kW }\end{array}$ & $\begin{array}{c}\text { Prędkość } \\
\text { posuwu, mm/s }\end{array}$ & Częstotliwość, Hz & Siła docisku, N & Długość spoiny, mm & $\begin{array}{l}\text { Rzeczywista dłu- } \\
\text { gość spoiny, mm }\end{array}$ \\
\hline 1 & 1 & \multirow{4}{*}{20} & \multirow{4}{*}{5} & \multirow{4}{*}{1} & \multirow{4}{*}{40} & \multirow{4}{*}{58} \\
\hline 2 & 1,5 & & & & & \\
\hline 3 & 2 & & & & & \\
\hline 4 & 2,5 & & & & & \\
\hline 5 & 1 & \multirow{4}{*}{20} & \multirow{4}{*}{10} & \multirow{4}{*}{1} & \multirow{4}{*}{40} & \multirow{4}{*}{75} \\
\hline 6 & 1,5 & & & & & \\
\hline 7 & 2 & & & & & \\
\hline 8 & 2,5 & & & & & \\
\hline
\end{tabular}

\section{Analiza wyników badań}

Zastosowane parametry spawania w przypadku złączy nr 1 nie pozwoliły uzyskać przetopu dolnej blachy, a w przypadku złącza nr 3 nastąpiło zbyt duże podtopienie blachy górnej, dlatego te złącza pominięto $w$ dalszych badaniach. Przeprowadzone badania wizualne wykonanych złączy nie wykazały wad spawalniczych wychodzących na powierzchnię typu: pęknięcia, porowatość. W przypadku złącza 4 i 8 można zaobserwować widoczne przetopienie blach na wskroś. Badania makroskopowe nie wykazały niezgodności spawalniczych dotyczących kształtu i wymiarów geometrycznych (rys. 5). W obszarze przetopionym pojawiają się pojedyncze pęcherze gazowe. Pęcherze te mogą powstawać w wyniku
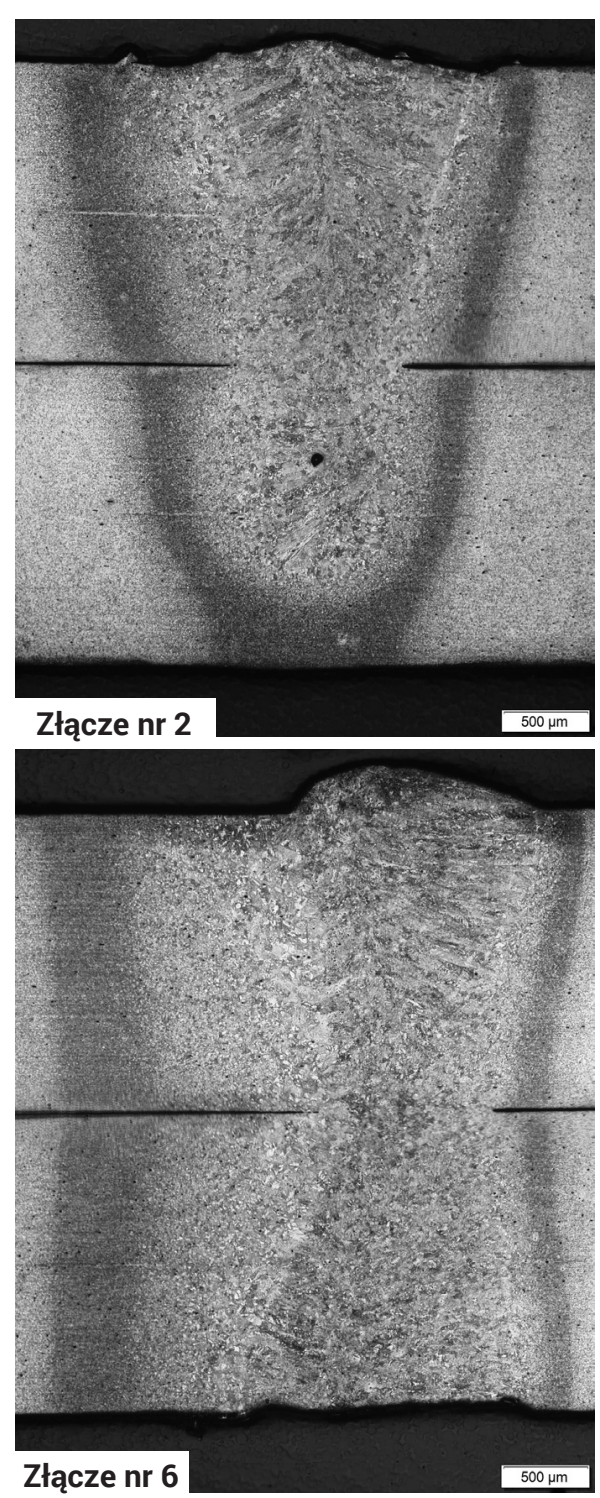

Rys. 5. Makrostruktura połączeń 2, 4, 5, 6, 7, 8
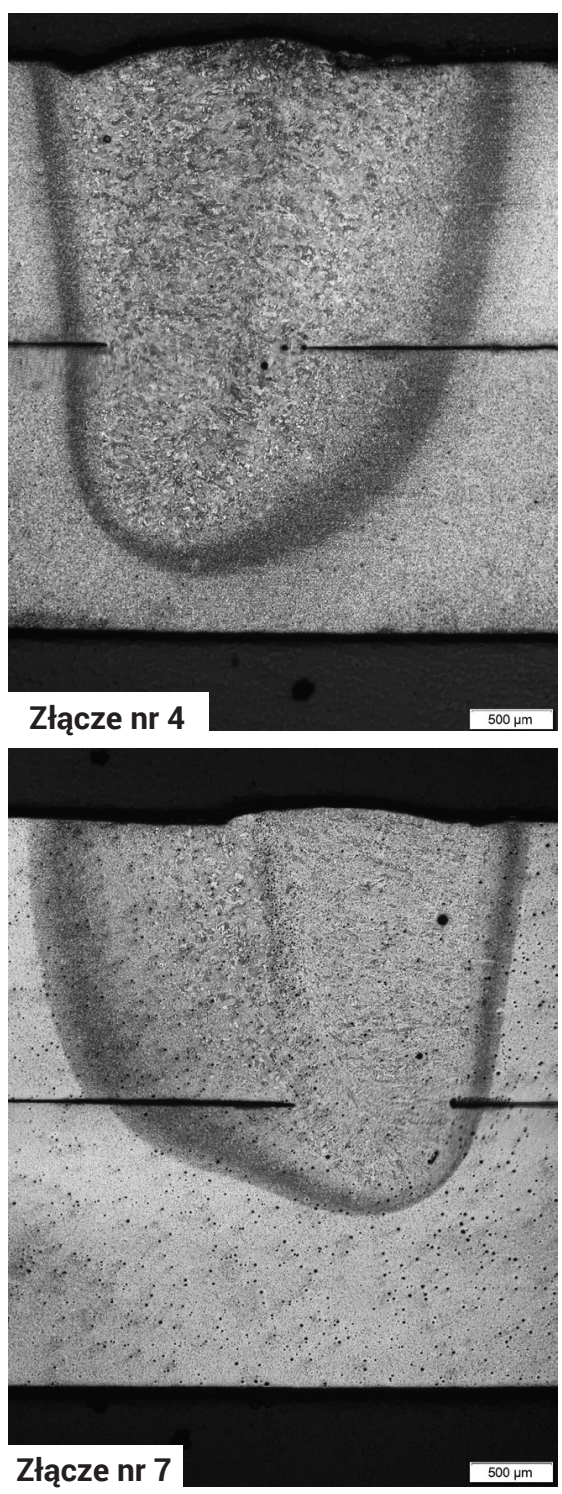

Fig. 5. The macrostructure of joints no. 2, 4, 5, 6, 7, 8
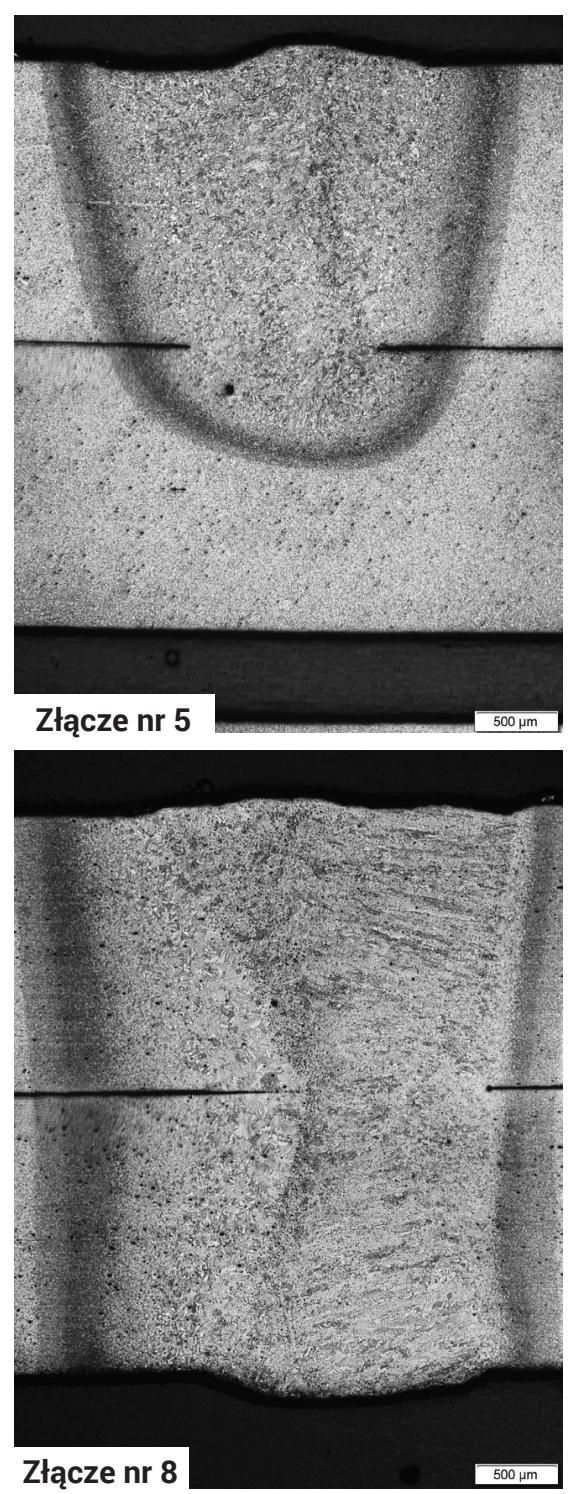
uwięzienia gazów rozpuszczonych w metalu bądź w wyniku odparowania pierwiastków stopowych lub ewentualnych zanieczyszczeń znajdujących się na powierzchni styku łączonych blach (rys. 6).

Przeprowadzone badania mikroskopowe wykazały, że struktura materiału rodzimego składa się z martenzytu odpuszczonego, natomiast w obszarze spoiny występuje martenzyt iglasty. Strefę wpływu ciepła charakteryzuje natomiast struktura z widocznymi efektami odpuszczania, rysunek 7 . Można zauważyć wyraźny wzrost wielkości ziarna w stosunku do wielkości pierwotnej w materiale rodzimym. Zależność ta jest widoczna zwłaszcza w strefie spoiny, gdzie rozrost ziarna jest największy. Wynika to z faktu, że w tym obszarze występowały najwyższe temperatury podczas procesu

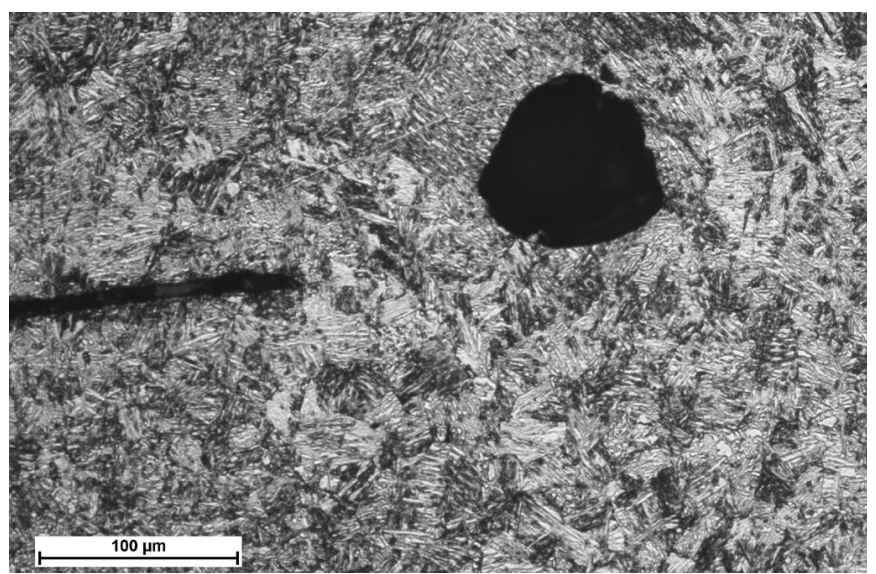

\section{Złącze $\mathrm{nr} 2$}

Rys. 6. Widok pęcherzy gazowych w połączeniu 2 i 4

Fig. 6. The view of gas blowholes in joints no. 2 and 4

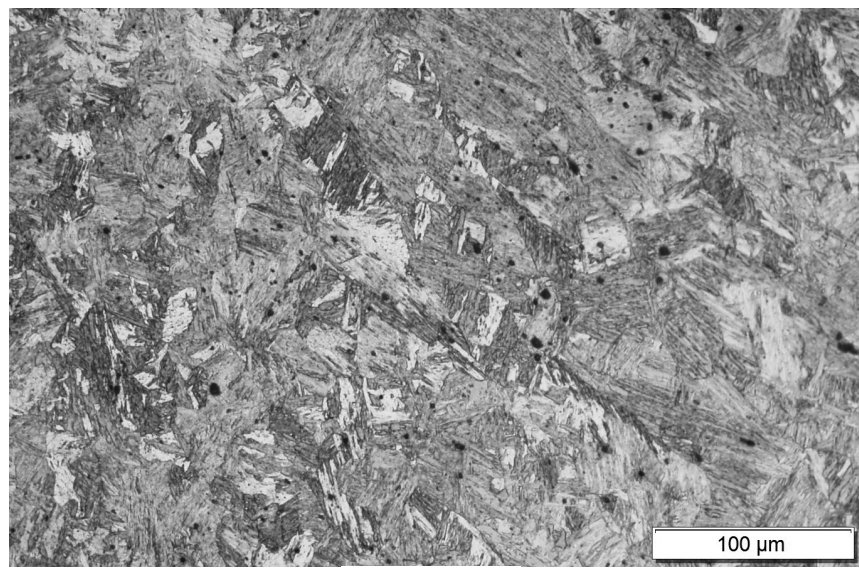

Spoina

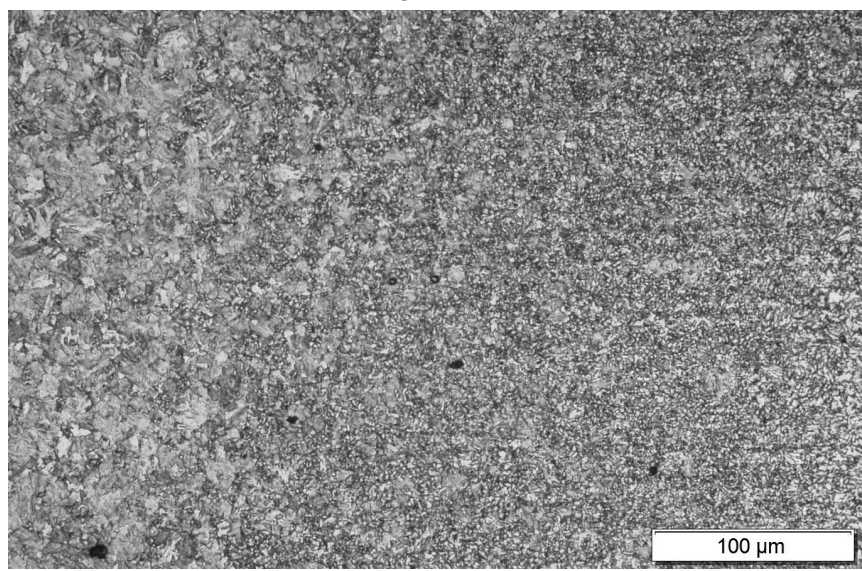

Przejście SWC - materiał rodzimy

Rys. 7. Mikrostruktura złącza nr 4

Fig. 7. The microstructure of joint no. 4 łączenia. Należy dodatkowo zaznaczyć, że zastosowane parametry procesu także silnie wpływają na wielkość ziarna w strefie wpływu ciepła.

Parametry zastosowane podczas wykonywania złączy zgrzewanych mają istotny wpływ na twardość strefy wpływu ciepła oraz obszarów przetopionych. Twardość obszarów przetopionych $\mathrm{w}$ zależności od parametrów procesu zgrzewania waha się w granicach od 380 do 415 HV1 i jest nieznacznie niższa od twardości materiału rodzimego (440 HV1), rysunek 8. W obszarze SWC dochodzi do procesu odpuszczania, w wyniku którego twardość spada do wartości od 270 do $320 \mathrm{HV} 1$, rysunek 9. Obniżenie twardości tych obszarów może wpływać na podwyższenie własności plastycznych połączeń.

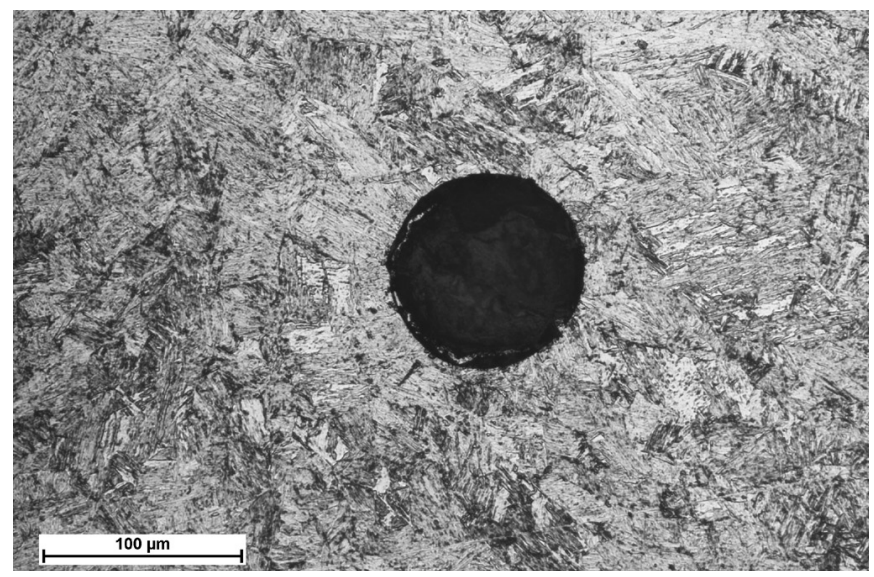

Złącze nr 4

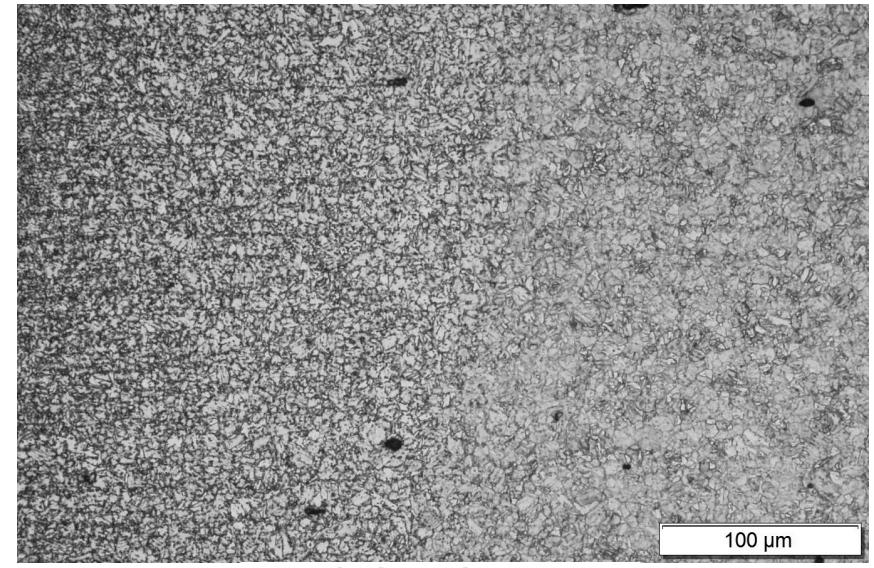

Przejście spoina - SWC

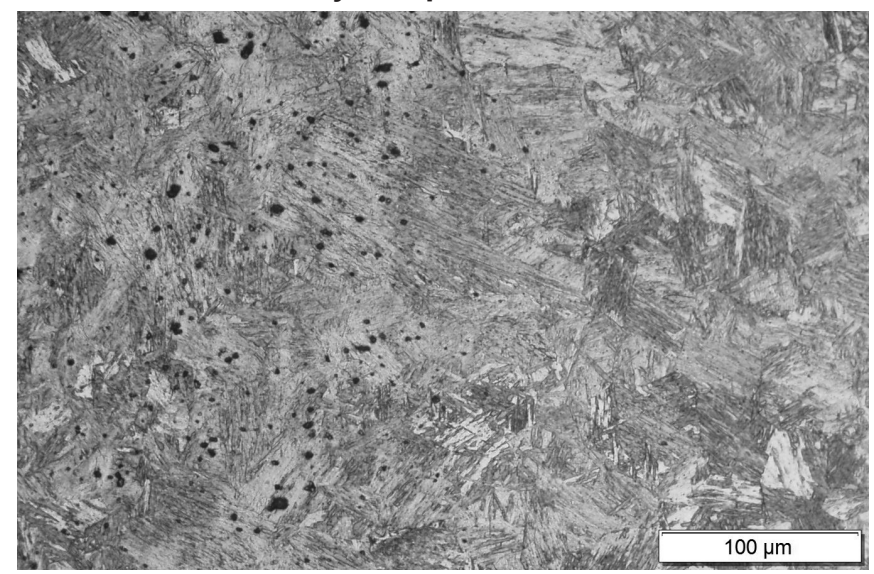

Materiał rodzimy 


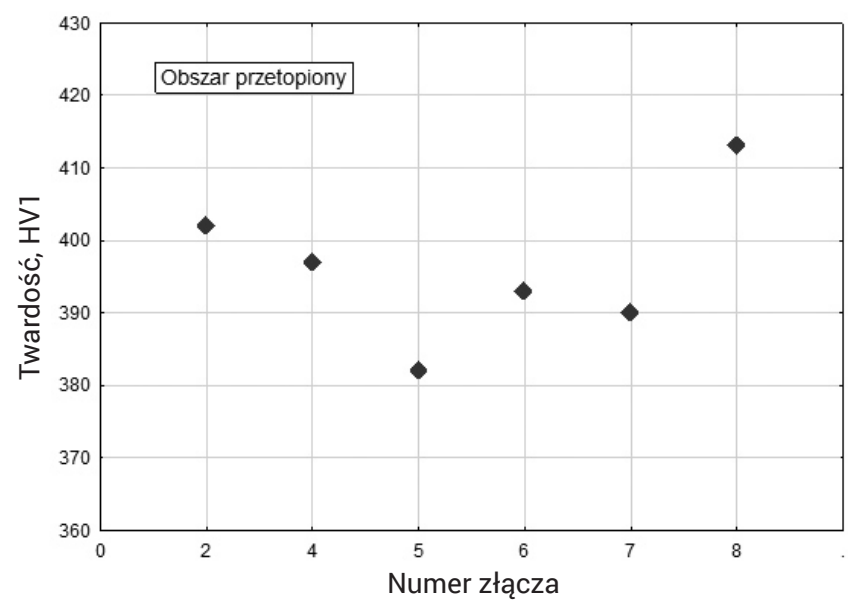

Rys. 8. Średnia z pięciu pomiarów twardości w obszarze spoiny Fig. 8. Average of five hardness measurements in the weld area

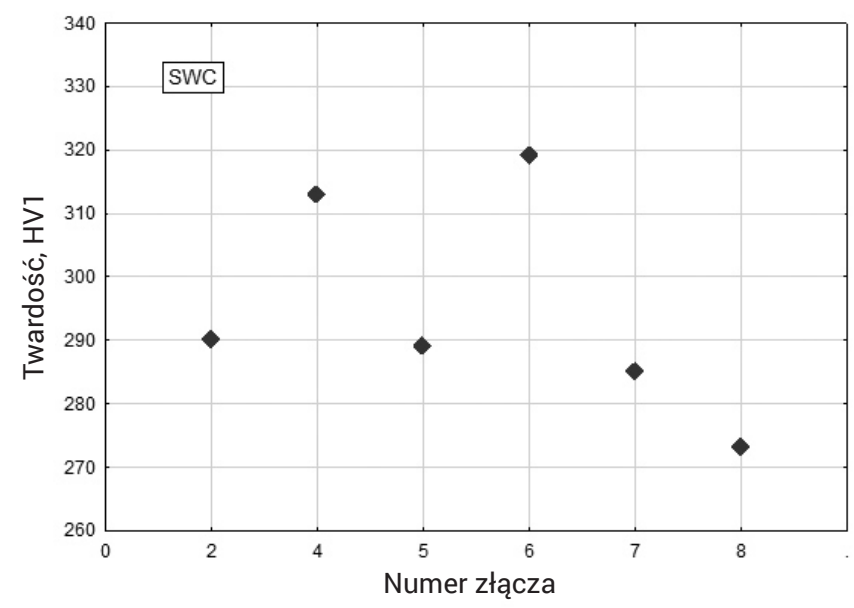

Rys. 9. Średnia z pięciu pomiarów twardości w obszarze SWC Fig. 9. Average of five hardness measurements in HAZ

\section{Podsumowanie}

Przeprowadzone badania procesu łączenia techniką Laser SEAM Stepper stali DOCOL 1200M o grubości 1,8 mm, wykazały, że istnieje możliwość wykonania złączy spawanych, spełniających wymagania stawiane przez przemysł motoryzacyjny. Poprzez odpowiedni dobór parametrów technologicznych można uzyskać połączenia z pełnym przetopem (w zależności od wymagań) lub połączenia bez pełnego przetopienia. Wszystkie wykonane złącza w obszarze przetopienia charakteryzują się strukturą martenzytu iglastego, o zmiennej wielkości igieł w zależności od ilości dostarczonej energii. W SWC materiał rodzimy został odpuszczony, co spowodowało powstanie strefy zmiękczonej. Wielkość spoiny oraz strefy zmiękczonej w badanych złączach wzrastała wraz ze wzrostem energii liniowej procesu łączenia. W celu redukcji wielkości strefy zmiękczonej, należy stosować parametry procesu ostre (możliwie krótkie czasy przy dużej mocy wiązki laserowej). W celu ograniczenia w obszarze przetopionym pęcherzy gazowych należy zwrócić szczególną uwagę na odpowiednie oczyszczenie blach z ewentualnych zanieczyszczeń znajdujących się na powierzchni styku łączonych materiałów.

\section{Literatura}

[1] Grajcar A., Różański M.: Spawalność wysokowytrzymałych stali wielofazowych AHSS, Przegląd Spawalnictwa nr 3/2014, str. 22-27.

[2] Nishioka K., Ichikawa K.: Progress in termomechanical control of steel plates and their commercialization, Science and Technology of Advanced Materials, vol. 13, No. 2, April 2012, pp. 1-20.

[3] Krajewski S., Nowacki J.: Mikrostruktura i właściwości stali o wysokiej wytrzymałości AHSS, Przegląd Spawalnictwa nr 7/2011, str. 45-50.

[4] Stano S.: Spawanie laserowe blach o zróżnicowanej grubości przeznaczonych na półfabrykaty karoserii samochodowych typu tailored blanks, Biuletyn Instytutu Spawalnictwa nr 2/2005, str. 24-28.

[5] Chen B., Yu H.: Hot ductility behaviour of V-N and V-Nb microalloyed steels, International Journal of Minerals, Metallurgy and Materials, vol. 19, No. 6, June 2012, p. 525.

[6] Lee, H. Shin, K. Park: Evaluation of high strength TMCP steel weld for use in cold regions, Journal of Constructional Steel Research 74 (2012) pp. 134-139.

[7] Górka J.: Weldability of thermomechanically treated steels having a high yield point, Archives of Metallurgy and Materials, Volume 60, Issue 1/2015, pp. 469-475.

[8] Lisiecki A.: Diode laser welding of high yield steel. Proc. of SPIE Vol. 8703, Laser Technology 2012: Applications of Lasers, 87030 S (January 22, 2013), DOI: $10.1117 / 12.2013429$
[9] Adamczyk J., Opiela M.: Influence of the thermo-mechanical treatment parameters on the inhomogeneity of the austenite structure and mechanical properties of the Cr-Mo steel with $\mathrm{Nb}$, Ti and B microadditions, Journal of Materials Processing Technology, vol. 157-158, 2004, pp. 456-461.

[10] Górka J.: Study of structural changes in S700MC steel thermomechanically treated under the influence of simulated welding thermal cycles, Indian Journal of Engineering and Materials Sciences, Vol. 22, October 2015, pp. 497-502.

[11] Grajcar A., Różański M., Stano S.: Effect of heat input on microstructure and hardness distribution of laser welded Si-AI TRIP-type steel, Advances Material Science Engineering. 2014, Article ID 658947, pp. 1-8.

[12] Godwin K., Yong O., Microstructure and fatigue performance of buttwelded joints in advanced high-strength steels, Materials Science \& Engineering A 597 (2014), pp. 342-348.

[13] Siewert A. Krastel K., Fiber Laser Seam Stepper Replacing Resistance Spot-Welding. A cost-effective laser based tool to conventional welding technology, Laser Technik Journal, 4/2014.

[14] Materiały firmy IPG Photonics, http://www.ipgphotonics.com 